\title{
Potensi Sapi Lokal Dalam Upaya Mewujudkan Kecukupan Daging Dan Pengembangan Kawasan Peternakan
}

\author{
A. Agustar dan Jaswandi \\ Jurusan Produksi Ternak Fakultas Peternakan Universitas Andalas \\ Kampus Limau Manis Padang
}

\begin{abstract}
The present paper discussed the contribution of animal production on protein consumption of the people of Indonesia The quite low protein intake is mainly caused the limited sources of food protein, which was indicated by relatively high price of animal product for food. In the contrary, Indonesia have many kinds indegineuous livestock animals, which have became a part of socio-ecomic live of the people, like Bali and Pesisir cattle.
\end{abstract}

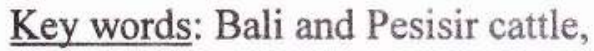

\section{Pendahuluan}

Pentingnya peranan ternak dalam mencapai tujuan pembangunan sudah banyak dibahas dan tidak diragukan lagi diberbagai negara. Sebagai komoditi penghasil protein hewani, ternak memiliki andil penting dalam perbaikan gizi, yang menjadi salah satu faktor. mempengaruhi kualitas sumberdaya manusia pada suatu bangsa. Berbagai bukti empiris menunjukkan bahwa tingkat konsumsi protein hewani suatu bangsa mempunyai korelasi yang positif dengan kualitas sumberdaya manusia bangsa tersebut.

Berbagai publikasi memperlihatkan bahwa tingkat konsumsi protein hewani penduduk Indonesia masih sangat rendah, hanya sekitar 6 gram/kapita/tahun. Sementara rata rata konsumsi penduduk dunia mencapai $26 \mathrm{gram} / \mathrm{kapita} / \mathrm{tahun} \mathrm{(Han,}$ 1999). Diantara negara - negara di Asia Tenggarapun, Indonesia masih tergolong memiliki penduduk dengan konsumsi protein hewani yang rendah. Apalagi dibandingkan dengan negara- negara maju seperti AS, Perancis, Inggris dan Jepang yang penduduknya mengkonsumsi protein hewani yang berkisar antara $50-80 \mathrm{gram} / \mathrm{kapita}$ /tahun.

Bila ditinjau lebih jauh, rendahnya konsumsi protein hewani terlihat dari rendahnya konsumsi daging, telur dan susu penduduk Indonesia. Konsumsi daging ayam misalnya pada tahun 2005 hanya 4,44 $\mathrm{kg} / \mathrm{kapita} /$ tahun, sedangkan Philipina $8,02 \mathrm{~kg} / \mathrm{kapita} /$ tahun; Thailand 15,28 $\mathrm{kg} / \mathrm{kapita} /$ tahun; Singapura $28,0 \mathrm{~kg}$ /kapita/tahun; dan Malaysia 36,74 $\mathrm{kg} / \mathrm{kapita} / \mathrm{tahun}$ (FAO, 2006).

Konsumsi telur unggas penduduk Indonesia juga masih rendah, dimana hanya $2,7 \mathrm{~kg} / \mathrm{kapita}$ /tahun, sedangkan Malaysia sudah mencapai angka $14,4 \mathrm{~kg} / \mathrm{kapita} / \mathrm{tahun}$, Thailand $(9,9 \mathrm{~kg})$, dan Filipina $(6,2$ $\mathrm{kg}$ ). Bila setiap $\mathrm{kg}$ telur setara dengan 17 butir, maka penduduk Indonesia baru memakan 45,9 butir telur setiap orangnya setiap tahun. Penduduk Malaysia telah mengkonsumsi sebanyak 245 butir telur setiap orangnya setiap tahun. Ini berarti 
bahwa orang Indonesia hanya makan sebutir telur setiap 8 hari, sedangkan orang Malaysia sudah mengkonsumsi 2 butir telur setiap tiga hari.

Tingkat konsumsi protein hewani asal ternak yang rendah berimplikasi terhadap tingkat kualitas hidup bangsa Indonesia. Pada tahun 2004 Indeks Pembangunan Manusia (HDI) berada pada peringkat 111 dari 177 negara di dunia. Sedangkan Singapura berada pada peringkat 25 , Malaysia 59, Thailand 76.

Khusus untuk daging, sebagian besar (56 \%) dari total konsumsi daging penduduk Indonesia masih berasal dari daging ayam, diikuti daging sapi (23\%), babi (13\%), kambing dan domba (5\%), dan sisanya (3 \%) berasal dari daging ternak lain-lain (Ditjennak, 2002). Untuk kebutuhan konsumsi daging sapi, baru mampu dipenuhi dari ternak sapi yang ada sebanyak $70 \%$ dari total kebutuhan pasar domestik, sementara sisanya $30 \%$ berasal dari impor daging dan sapi bakalan/potong.

\section{Eksistensi Ternak Sapi Sebagai Penghasil Daging}

Dalam Revitalisasi Pertanian, Perikanan dan Kehutanan (RPPK), sebagai salah satu dari strategi tiga jalur (triple track strategy) yang digunakan Pemerintahan Kabinet Indonesia Bersatu pimpinan Presiden Susilo Bambang Yodhoyono (SBY), ternak sapi termasuk salah satu dari 5 komoditas terpenting disamping padi, kedelai jagung dan gula.

Prediket komoditas terpenting ditetapkan untuk ternak sapi di Indonesia karena sapi memiliki multi fungsi yang strategis sebagai penghasil daging, susu dan tenaga kerja pengolah lahan. Selain itu, sapi juga berperan sebagai sumber pendapatan, bio investasi, asset cultural dan religius, sumber gas bio untuk memenuhi kebutuhan energi dan pupuk kandang. Multi fungsi yang dimiliki ternak sapi tersebut, relevan dengan tekad pemerintah disektor pertanian yang menjadi tujuan RPPK yaitu; meningkatkan kesejahteraan petani dan mengurangi kemiskinan; menciptakan kesempatan usaha dan kesempatan kerja baru; membangun ketahanan pangan; meningkatkan daya saing; dan melestarikan lingkungan.

Substansi dari setiap butir tekad tersebut melandasi apa yang dicanangkan Menteri Pertanian yaitu Program Kecukupan Daging khususnya daging sapi pada tahun 2010 .

Bila dilihat kondisi eksisting pasokan daging sapi untuk memenuhi perminataan pasar domestik yang ada, maka disadari bahwa untuk jangka waktu 3 tahun kedepan yang masih tersisa, apa yang dicanangkan tersebut merupakan tugas berat bagi setiap pemangku kepentingan yang berkaitan dengan produksi daging sapi. Sejauh ini lebih kurang $30 \%$ dari permintaan dalam negeri dipenuhi dengan daging sapi (+ jeroan ) impor dari negara-negara pengekspor sapi atau daging sapi, khususnya Australia dan AS. Bila dilihat data yang dipublikasikan oleh Departemen Pertanian (USDA) AS misalnya, Indonesia merupakan negara tujuan ekspor dengan jumlah terbesar diantara negara-negara tujuan lainnya. 
Tabel 1. Jumlah Import Daging Sapi dan Jeroan dari AS (ton)

\begin{tabular}{ccc}
\hline Tahun & Daging & Jeroan \\
\hline 1999 & 2.707 & 746 \\
2000 & 6.667 & 600,8 \\
2001 & 6.781 & 1.225 \\
2002 & 7.948 & 742 \\
2003 & 12.218 & 1.567 \\
2004 & 7.158 & 1.989 \\
\hline
\end{tabular}

Sumber : PPSKI, 2004.

Dalam periode pelarangan import daging dari US pun, PPSKI masih mencatat misalnya bulan April 2005 lebih dari 1000 ton daging sapi diimport dari USA.

Tingginya jumlah impor tersebut selain menguras devisa negara juga bertentangan dengan apa yang menjadi tekad pemerintah untuk komoditas ternak sapi seperti apa yang dikemukakan dalam strategi Revitalisasi Peternakan Indonesia. Besarnya jumlah impor daging, sapi bakalan dan sapi potong mencerminkan bahwa ketersediaan ternak sapi domestik yang ada tidak mampu memenuhi permintaan, walaupun tingkat konsumsi daging sapi penduduk Indonesia masih relatif rendah dibandingkan dengan konsumsi penduduk negaranegara lain di Asia Tenggara sekalipun, terutama Singapura dan Malaysia.

Pada tahun 2001 populasi ternak sapi di Indonesia tercatat 11,9 juta ekor $^{1}$, yang terdiri dari sapi asli/lokal (sapi Bali, sapi Madura, sapi Pesisir, sapi PO), dan sapi eksotik yang diimpor dari luar negeri (Simmental, Brahman).

Kebijakan pembangunan Peternakan khususnya untuk ternak sapi cendrung berpihak kepada sapi eksotik dibandingkan dengan sapi lokal,

\footnotetext{
${ }^{1}$ pertumbuhan populasi tidak signifikan sehingga saat ini populasi sapi Indonesia juga tidak berbeda signifikan dengan data tersebut.
}

walaupun susungguhnya kontribusi sapi lokal yang dipelihara peternakan rakyat jauh lebih besar untuk mencukupi kebutuhan daging sapi domestik. Sebagai penghasil daging, sapi lokal memiliki sejumlah keunggulan, walaupun tidak dipungkiri bahwa bangsa sapi lokal juga mempunyai sejumlah kekurangan dibandingkan dengan jenis sapi eksotik yang pada umumnya didatangkan dari daerah sub-tropis.

\section{Performans Sapi Lokal}

Salah satu pertimbangan penting dalam pengembangan usaha peternakan sebagai proses produksi adalah tingkat efisiensi ternak yang dipelihara menggunakan sumberdaya untuk menghasilkan produk yang diharapkan. Misalnya pada situasi tertentu jenis sapi tertentu memiliki tingkah laku dan kebutuhan pakan yang tidak mampu didukung oleh sumberdaya pakan yang ada pada wilayah dimana ia dipelihara. Kondisi yang demikian akan menyebabkan ia tidak dapat menampilkan kemampuan produksinya secara optimal, dan bahkan ada kemungkinan sulit untuk bertahan.

Sapi lokal memiliki kemampuan yang lebih baik beradaptasi dengan lingkungan tropis dibandingkan dengan sapi-sapi eksotik. Selain itu, tingkat resistensi terhadap penyakit tropis juga lebih tinggi. Dua hal tersebut merupakan keunggulan 
utama sapi lokal yang tidak dimiliki oleh sapi-sapi yang didatangkan dari negara-negara yang memiliki 4 musim.

Percobaan pada sapi-sapi muda (berat badan $250-300 \mathrm{~kg}$ ) dilaporkan Hart and McDowell (1985) bahwa jenis sapi Bos taurus (BT) lebih rendah efisiensi penggunaan pakan tropis (hijauan + suplement) di bandingkan dengan jenis sapi Bos indicus (BI). Lebih baiknya efisiensi penggunaan pakan pada BI menghasilkan ADG yang lebih baik dibandingkan dengan BT. Selain lebih efisien dalam merubah pakan menjadi daging, BI juga dilaporkan memiliki bentuk kepala dan perototan yang memanjang sehingga menyebabkan ia memiliki tingkah laku merumput yang berbeda dengan BT.

Jenis sapi BI memiliki tingkah laku mendapatkan hijauan dari pohonpohon atau semak-semak, tidak hanya pada padang rumput. Tingkah laku yang demikian sangat cocok dengan kondisi lingkungan didaerah tropis yang pada umumnya pemeliharaan ternak sapi tidak dilakukan pada padang rumput khusus sebagai sumber hijauan.

Dari aspek reproduksi, sudah banyak laporan yang mengatakan bahwa jenis ternak sapi lokal Indonesia mempunyai potensi daya reproduksi yang tinggi. Sebagai contoh sapi Bali yang telah lama diketahui mempunyai fertilitas yang tinggi. Fertilitas sapi Bali berkisar 83 $86 \%$, lebih tinggi dibandingkan sapi Eropa hanya $60 \%$. Karakteristik reproduktif antara lain : periode kekebuntingan 280 - 294 hari, ratarata persentase kebuntingan $86,56 \%$, tingkat kematian kelahiran anak sapi hanya $3,65 \%$ dan persentase kelahiran $\pm 83 \%$.

Demikian juga halnya dengan sapi lokal lainnya seperti sapi Pesisir yang mempunyai tingkat adaptasi yang baik pada kondisi lingkungan yang jelek. Namun demikian keunggulan - keunggulan tersebut belum dapat termanfaatkan secara optimal sehingga pilihan untuk memelihara sapi belum diberikan prioritas terhadap ternak lokal tersebut.

Tabel 2. Pengaruh Type Pakan Suplement dan Intake Pucuk Tebu Sebagai Sumber Hijauan Terhadap ADG (kg) pada Jenis Sapi BT dan $B I$

\begin{tabular}{lccc}
\hline $\begin{array}{c}\text { Jenis Sapi dan Type } \\
\text { Pakan }\end{array}$ & $\begin{array}{c}\text { Intake/d* } \\
\text { Pucuk Tebu } \\
(\mathrm{kg})\end{array}$ & $\begin{array}{c}\text { Supplement } \\
(\mathrm{kg})\end{array}$ & $\begin{array}{c}\text { ADG } \\
(\mathrm{kg})\end{array}$ \\
\hline $\begin{array}{l}\text { Bos Taurus } \\
\text { Pucuk tebu }\end{array}$ & 17 & 0,0 & 0,06 \\
+ Molasses & 15 & 1,4 & 0,03 \\
+ Cassava,wet & 16 & 1,3 & 0,06 \\
+ Cottonseed meal & 23 & 1,6 & 0,75 \\
\hline Bos Indikus & & & \\
Pucuk tebu & 16 & 0,0 & 0,10 \\
+ Molasses & 12 & 1,2 & 0,04 \\
+ Cassava,wet & 14 & 1,2 & 0,08 \\
+ Cottonseed meal & 21 & 1,4 & 0,87 \\
\hline
\end{tabular}

* offered free choice

Sumber : McDowell, 1985. 
Walaupun ternak lokal memiliki potensi daya reproduksi yang tinggi, kinerja reproduksi ternak lokal yang direpresentasikan oleh tingkat kelahiran ternak belum menggembirakan. Hanya di daerah yang telah menerapkan perkawinan dengan inseminasi buatan tingkat kelahiran ternak yang sudah memadai sekitar $40-70 \%$ (Laboratorium Reproduksi Fakultas Peternakan, 2006), diluar daerah itu tingkat kelahiran ternak masih rendah sekitar $30 \%$.

Tingkat kelahiran ternak lokal yang masih rendah disebabkan oleh beberapa faktor seperti manajemen yang diterapkan peternak dan kondisi ternak itu sendiri. Faktor manajemen misalnya dari aspek Skala usaha yang relatif kecil serta orientasi pemeliharaan sebagai usaha sambilan. Kondisi yang demikian menyebabkan intensitas pengamatan peternak pada ternaknya relatif kurang, sehingga berbagai fenomena biologis seperti status birahi sering terlewatkan. Disamping itu saat perkawinan yang tepat waktu yang dapat menghasilkan kebuntingan menjadi terabaikan. Hal ini menyebabkan perkawinan kembali setelah melahirkan menjadi lebih panjang dan sering menimbulkan kawin berulang.

Hasil penelitian pada peternak sapi yang dikawinkan secara Inseminasi Buatan di berbagai Kabupaten di Propinsi Sumatera Barat menunjukkan bahwa kawin kembali pasca melahirkan berkisar $2-6$ bulan dan jumlah service per conception (S/C) memiliki kisaran 1,3 - 1,8 serta calving rate berkisar 38,06 - $70 \%$ (Lab. Reproduksi Fakultas Peternakan, 2006).

Periode perkawinan pasca melahirkan berkorelasi langsung dengan jarak melahirkan (calving interval). Jarak melahirkan sapi rakyat yang dikawinkan secara IB adalah 427 - 463 hari (Bestari et al., 1999), sedangkan pada sapi rakyat yang dikawinkan secara alam mempunyai jarak melahirkan yang lebih lama yaitu berkisar 360-720 hari.

Jarak melahirkan yang masih belum optimal menyebabkan peternak belum dapat untuk memperoleh satu anak per tahun dari setiap ekor induk. Akan tetapi kegagalan tersebut belum dianggap sebagai kerugian karena pemeliharaan ternak hanya sebagai usaha sambilan dan peternak belum berperan sebagai producer bibit. Dalam skala nasional keadaan ini akan menjadi kendala dalam penyediaan bibit atau bakalan untuk menunjang program ketersediaan daging secara berkelanjutan pada tahun 2010 seperti yang telah dicanangkan.

\section{Potensi Sapi Pesisir}

Sapi pesisir merupakan jenis sapi asli yang berkembang di kawasan pesisir Sumatera Barat. Saladin (1983) menduga sapi pesisir sebagai sisa sapi asli yang pada mulanya berkembang di Kabupaten Pesisir Selatan, Sumatera Barat. Namun saat ini sapi pesisir juga ditemukan di Kabupaten Padang Pariaman dan Kabupaten Agam serta beberapa daerah lainnya di Sumatera Barat dan Riau. Di Sumatera Barat diperkirakan sapi pesisir $20 \%$ dari total sapi penghasil daging yang ada, dan memainkan peranan yang penting sebagai penghasil daging. Sebanyak $75 \%$ dari jumlah sapi yang dipotong pada Rumah Potong Hewan $(\mathrm{RPH})$ kota Padang adalah jenis sapi pesisir. Selain itu, sapi pesisir merupakan ternak yang populer untuk kebutuhan hewan qurban pada hari raya Idul Adha.

Sebagai sapi asli, sapi pesisir memiliki karakteristik spesifik dan 
berbeda dengan jenis sapi lainnya. Bobot badan relatif kecil dimana jantan dewasa umur 4-6 tahun memiliki bobot rata-rata $186 \mathrm{~kg}$, jauh lebih rendah dari bobot badan sapi asli Indonesia lainnya seperti sapi Bali untuk kisaran umur yang sama (310 $\mathrm{kg}$ ), dan sapi Madura (248 kg) .

Meskipun tergolong memiliki bobot kecil, sapi pesisir memiliki persentase karkas yang cukup tinggi. Menurut Saladin (1983), persentase karkas sapi pesisir adalah 50,6 persen, lebih tinggi dari persentase karkas sapi Ongole $(48,8 \%)$, sapi Madura $(47,2$ $\%)$, PO (45\%). Namun sedikit lebih rendah dari persentase karkas sapi Bali $(56,9 \%)$. Tingginya persentase karkas tersebut menunjukkan bahwa sapi pesisir merupakan salah satu jenis sapi lokal yang memiliki potensi yang tinggi untuk menghasilkan daging.

Sapi pesisir pada umumnya dipelihara secara ekstensif-tradisional, dan bahkan tidak jarang dipelihara secara bebas berkeliaran dengan perhatian peternak pemelihara yang sangat minim dengan skala pemeliharaan $2-5$ ekor per peternak. Daya adaptasi dengan kondisi lingkungan yang tidak memiliki sumber pakan yang baik terutama diwilayah pesisir tinggi. Selain itu dengan bobot yang kecil juga lebih efisien dalam memanfaatkan ruang.

Dengan sejumlah keunggulan tersebut, maka melirik sapi pesisir yang merupakan sapi lokal Indonesia sebagai penghasil daging terutama untuk kawasan pesisir adalah sesuatu yang menjanjikan.

Negara Indonesia merupakan negara kepulauan yang terdiri dari 17.506 buah pulau besar dan kecil dan memililiki panjang garis pantai 81.000 km. Dahuri (2004) memperkirakan sekitar $60 \%$ penduduk Indonesia bermukim di kawasan pesisir.
Tingginya konsentrasi permukiman penduduk membuat kawasan ini menjadi amat penting dalam proses pembangunan. Disisi lain, sebagian besar masyarakat yang bermukim pada wilayah pesisir memiliki taraf hidup yang rendah dan rawan pangan. Tidaklah mengherankan pada kawasan ini sering menjadi kantong-kantong kemiskinan. Konsumsi protein hewani penduduk rendah dan kasus malnutrisi banyak didapatkan pada kawasan ini.

Pengembangan sapi lokal Pesisir pada kawasan pesisir pantai dan pulau-pulau kecil di seluruh Indonesia merupakan alternatif kebijakan yang menjanjikan untuk meningkatkan produksi dan ketersediaan daging nasional.

\section{Penutup}

Bertolak dari kondisi usaha peternakan untuk ternak sapi di Indonesia, peningkatan kinerja ternak lokal akan ikut menentukan keberhasilan pencapaian program swasembada daging. Usaha pemeliharaan ternak sapi yang pada umumnya belum berorientasi bisnis secara penuh dan sering merupakan komponen usaha tani lainnya. Pemilihan ternak lokal seperti sapi pesisir yang mampu beradaptasi pada lingkungan yang kurang menguntungkan dan memiliki sejumlah keunggulan terutama untuk kawasan pesisir merupakan sesuatu yang menjanjikan.

Namun demikian perlu peningkatan peran peternak pada aspek sosial ekonomi seperti peningkatan skala usaha dan perubahan peran peternak dari pemelihara menjadi producer perlu dilakukan. Rendahnya perhatian dalam hal reproduksi misalnya mengakibatkan sapi lokal belum menampilkan sifat-sifat reproduksinya yang optimal. Perkawinan 
ternak tepat waktu memberikan peluang keberhasilan bunting yang lebih tinggi sehingga dapat memperpendek periode kosong setelah melahirkan sekaligus me-ngurangi lamanya calving interval.

Perluasan cakupan wilayah maupun peningkatan kinerja penerapan bioteknologi IB secara tidak langsung akan meningkatkan kinerja reproduksi ternak sapi. Penerapan teknologi ini, akan mendorong peternak untuk meningkatkan intensitas pengamatan pada ternaknya.

\section{Daftar Pustaka}

Agustar A. 2001. The Indogennous Cattle and Its contribution to the Rural Haousehold : West Sumatera Case. ISSAS Proc. Vo.VIII. 2001.

Agustar A. 2004. Peningkatan Produktifitas Penduduk Melalui Usaha Peternakan pada Wilayah Pedesaan. Seminar Nasional Pengentasan Kemiskinan di Wilayah Pedesaan. Bappenas. Jakarta.

Bestari, J., A.R. Siregar, Y. Sani dan P. Situmorang. 2000. Produktifitas empat bangsa pedet Sapi Potong hasil IB di Kabupaten
Agam Propinsi Sumatera Barat. Seminar Nasional dan Expo Hasil-Hasil Penelitian. BPT Bogor.

Laboratorium Reproduksi Fakultas Peternakan. 2006. Kompilasi Penelitian Tingkat Keberhasilan Inseminasi Buatan di Berbagai Kabupaten di Sumatera Barat. Fakultas Peternakan Universitas Andalas.

McDowell. 1985. Meeting constraints to Livestock Production system in Asia. In : Proceedings of regional Workshop on Livestock Production Management, ADB, Manila.

Ryadi, M. 2006. Kebijakan dan Rencana Strategis Pembangunan Peternakan 2006-2010. Seminar Nasional. Peranan Bioteknologi Reproduksi Dalam Pembangunan Peternakan dan Perikanan di Indonesia. Bogor.

Tappa, B. 2006. Aplikasi Bioteknologi Reproduksi Ternak di Indonesia. Seminar Nasional. Peranan Bioteknologi Reproduksi Dalam Pembangunan Peternakan dan Perikanan di Indonesia. Bogor.

Alamat Korespondensi: Dr. Ir. Asdi Agustar, M.Sc

Jurusan Produksi Ternak, Fakultas Peternakan

Universitas Andalas, Kampus Limau Manis, Padang

HP : 08126602162

Artikel diterima 25 September 2006, disetujui 9 Oktober 2006. 